\title{
ANALISIS FAKTOR MUNCULNYA GEJALA STRES PADA MAHASISWA AKIBAT PEMBELAJARAN JARAK JAUH DI MASA PANDEMI COVID-19
}

\author{
Rira Kartika \\ S1 Psikologi Fakultas Kedokteran Universitas Lambung Mangkurat \\ Rirakartika@gmail.com
}

\begin{abstract}
ABSTRAK
Gejala stres pada mahasiswa semakin meningkat setelah pandemi Covid-19 menyerang. Masalah psikologis yang sering muncul dan dialami oleh mahasiswa adalah kecemasan berlebih, stres, hingga depresi. Hal ini terkait dengan pembelajaran jarak jauh yang memberikan beberapa efek pemicu bagi mahasiswa. Tujuan dari analisis ini adalah untuk mengetahui faktor munculnya gejala stres pada mahasiswa akibat pembelajaran jarak jauh di masa pandemi covid-19. Metode yang digunakan adalah metode kajian literatur dengan mengambil beberapa sumber yang terdiri dari artikel, buku elektronik, jurnal, dan makalah. Kriteria inklusi pencarian sumber literatur adalah bersumber dari tulisan para dosen pengajar dan sumber lainnya yang berhubungan dengan psikologis dan Covid-19. Kata kunci pencaharian yaitu mahasiswa, stres, psikologi, dan Covid19. Kesimpulan yang didapat adalah sebagian besar mahasiswa mengalami stres karena beberapa faktor yang diakibatkan pembelajaran jarak jauh di masa pandemi covid-19.
\end{abstract}

Kata kunci: mahasiswa, belajar, stres, covid-19

\section{PENDAHULUAN}

Pendidikan merupakan proses pengubahan sikap dan tata laku seseorang atau kelompok orang dalam usaha mendewasakan manusia melalui upaya pengajaran dan pelatihan yang sesuai prosedur pendidikan itu sendiri (Khofifah \& Minsih, 2016). Tahapan tertinggi dalam pendidikan sendiri yaitu menjadi seorang mahasiswa (Amini et al., 2020). Seorang mahasiswa merupakan calon tenaga profesional yang akan menjadi pendorong pembangunan bangsa (Rachmah, 2015).

Sejak tanggal 11 Maret 2020 WHO menetapkan corona virus disease 2019 (covid-19) sebagai pandemi berskala global, banyak negara di dunia yang menetapkan kebijakan social distancing dan bahkan physical distancing untuk menghambat penyebaran Covid-19. Hal ini sejalan dengan rekomendasi Organisasi Kesehatan Dunia (WHO) melalui International Health 
Regulations (2005) Emergency Committee pada 30 Januari 2020 untuk melakukan social distancing dengan tujuan untuk melindungi mereka yang berisiko tinggi terhadap morbiditas dan penyakit terkait COVID-19 (Nicole K. Le, 2020).

Diketahui karena penetapan tersebut, tempat-tempat yang memungkinkan terjadinya kerumunan dan kontak fisik harus ditutup, tak terkecuali tempat-tempat dalam ruang lingkup pendidikan. Penutupan ini menjadi langkah paling efektif untuk mengurangi penyebaran virus pada siswa dan mahasiswa (Hasanah \& Setiawan, 2020). Perguruan tinggi juga menjadi salah satu lembaga Pendidikan yang terdampak dari pandemi covid-19 setelah lembaga pendidikan pada tingkat pra sekolah, tingkat dasar, tingkat menengah pertama dan juga pada tingkat menengah atas (Hasanah et al., 2020). Penutupan perguruan tinggi sendiri dilakukan secara fisik, artinya hanya gedung kampus yang ditutup tetapi kegiatan pembelajaran dan kegiatan yang bersifat administratif lainnya tetap dikerjakan secara jarak jauh (Firman, 2020). Dampak penutupan lembaga pendidikan akibat pandemi COVID-19 berdampak besar dalam proses pembelajaran dan kurikulum pendidikan (Rahmawati, 2020).
Pembelajaran jarak jauh menjadi sebuah solusi alternatif yang diambil setelah Kementerian Pendidikan dan Kebudayaan (Kemendikbud) mengeluarkan surat edaran tentang pembelajaran secara daring dalam rangka pencegahan penyebaran corona virus disease (Covid-19). Pembelajaran jarak jauh merupakan metode pembelajaran yang menggunakan jaringan internet dengan konektivitas, aksesibilitas, fleksibilitas, dan kemampuan untuk memunculkan berbagai jenis interaksi pembelajaran (Sadikin \& Hamidah, 2020). Perubahan proses belajar dari tatap muka menjadi pembelajaran jarak jauh merupakan suatu keputusan yang harus diambil oleh universitas agar pembelajaran masih dapat berlangsung sebagaimana mestinya. Berbagai perubahan harus dilakukan oleh universitas dan hal ini menjadi tantangan tersendiri bagi setiap universitas untuk tetap mejalankan tujuan pendidikan. Kebijakan pemindahan kegiatan belajar dari sekolah ke rumah berdampak pada perubahan model pembelajaran. Kini, baik mahasiswa maupun dosen harus menggunakan aplikasi online seperti Google Classroom, Zoom, dan fasilitas lainnya untuk menunjang kegiatan pembelajaran.

Perubahan pembelajaran tatap muka menjadi pembelajaran online yang 
dilaksanakan secara mendadak membuat pembelajaran tidak dapat berjalan dengan maksimal (Irawati \& Jonatan, 2020). Seiring berjalannya waktu pembelajaran jarak jauh menjadi berdampak pada psikologis mahasiswa. Mahasiswa mulai mengeluhkan beberapa hal seperti kendala jaringan, terbatas dan borosnya paket data karena harus melakukan pertemuan online melalui aplikasi zoom, sulitnya pengerjaan tugas kelompok, bahkan pembelajaran daring yang baru dilakukan beberapa hari saja mahasiswa sudah diberikan banyaknya tugas, sampai di titik stres akan mengerjakan tugas yang harus diprioritaskan terlebih dahulu. Hal ini kemudian berdampak pada kesehatan mental mahasiswa hingga menimbulkan gejala stres.

Stres sendiri adalah kondisi seseorang individu yang mengalami ketidakseimbangan karena ketidaksesuaian antara apa yang diinginkan dengan kenyataan dan mempengaruhi perilaku individu tersebut (Sandra \& Ifdil, 2015). Masalah yang dialami mahasiswa pada masa pandemi Covid-19 ini seperti tuntutan-tuntutan yang dibebankan dengan model belajar mengajar secara daring membuat mereka tertekan dan akhirnya menimbulkan gejala stres (Muslim, 2020). Gejala dari stres yang dialami mahasiswa tersebut dapat berdampak kepada gangguan pola tidur atau sulit untuk tidur, sakit kepala, gelisah, mudah marah dan kelelahan fisik (Wahyuni, 2018).

Untuk itu, melalui penelitian ini akan dipelajari lebih jauh apa saja faktor penyebab munculnya gejala stres pada mahasiswa yang timbul akibat pembelajaran jarak jauh di masa pandemi covid-19.

\section{METODE PENELITIAN}

Metode yang digunakan dalam penulisan ini adalah metode kajian literatur. Sumber literatur terdiri dari artikel, buku elektornik, jurnal, dan makalah. Kriteria inklusi pencarian sumber literatur adalah bersumber dari tulisan para dosen pengajar di program studi psikologi fakultas kedokteran Universitas Lambung Mangkurat dan sumber lainnya yang berhubungan dengan psikologis, stres, dan Covid-19. Kata kunci pencaharian yaitu mahasiswa, psikologi, stres, Covid-19. Total sumber literatur yang digunakan untuk analisa berjumlah 37 sumber (buku, jurnal, artikel, makalah), dengan 10 sumber berasal dari tulisan para dosen pengajar. Teknik pengumpulan data dilakukan secara digital. Setelah mencari dari berbagai sumber selanjutnya data dikembangkan hingga terbentuk pengetahuan baru dan dituliskan dalam artikel ini. 


\section{HASIL DAN PEMBAHASAN}

Dari artikel-artikel tersebut didapatkan hasil berupa faktor-faktor yang menjadi penyebab munculnya gejala stres pada mahasiswa.

Berdasarkan hasil penelitian Livana et al,. (2020) penyebab stres mahasiswa selama pandemi Covid-19 yang banyak dikemukakan adalah tugas perkuliahan. Banyaknya tugas yang dianggap berlebih dengan tuntutan waktu pengumpulan yang tergolong cepat membuat kesehatan mental mahasiswa terganggu. Mahasiswa menjadi tidak bisa beristirahat cukup karena ada banyak tugas yang harus diprioritaskan terlebih dahulu.

Lingkungan belajar yang berbeda saat melakukan pembelajaran jarak jauh. Hal ini juga menjadi salah satu faktor. Ada beberapa mahasiswa yang menjalani pembelajaran jarak jauh di tempat kost dan asrama yang kondisinya berbeda dengan pembelajaran tatap muka yang biasa dilakukan di kelas. Hal ini dialami beberapa mahasiswa yang tidak bisa pulang ke kampung halaman karena kebijakan pemerintah tentang pembatasan operasional transportasi di masa pandemi covid-19, membuat beberapa mahasiswa harus tetap berada di kost ataupun asrama. Mereka mengatakan bahwa terkadang perasaan sesak karena ruangan yang sempit.
Sementara pada mahasiswa yang tinggal di asrama mengatakan bahwa mereka sering merasakan sesak karena ruang kamar yang di huni 2 (dua) sampai 4 (empat) orang perkamar (Maihayana et al,. 2020). Lingkungan seperti ini sungguh tidak kondusif untuk dipakai sebagai tempat belajar karena keterbatasan ruang. Lingkungan fisik sangat berperan dalam membuat suasana kondusif yang mendorong peserta didik untuk belajar (Mayangsari \& Astuti, 2020).

Berbeda dengan mahasiswa yang berada di kost ataupun asrama, masalah yang dihadapi mahasiswa yang pulang kampung dan tinggal di adalah kebisingan karena lingkungan rumah yang berisik hingga mengganggu konsentrasi dalam belajar. Proses belajar sendiri tidak hanya dipengaruhi oleh faktor internal melainkan juga faktor eksternal, yaitu kondisi lingkungan sekitar belajarnya. Apabila kebisingan terjadi saat mahasiswa sedang memahami materi yang diajarkan, kebisingan yang sangat rendah juga dapat mengganggu, sumber kebisingan tidak hanya dari dalam ruangan tetapi juga mencakup wilayah yang lebih luas seperti di luar dan sekeliling ruang belajar (Zwagery et al., 2019). Menurut Feidihal (2007) dalam Zwagery et al., (2019), kebisingan yang terjadi dapat berdampak pada beberapa hal, salah satunya gangguan 
psikologis. Kebisingan dapat menimbulkan masalah psikologis seperti perasaan jengkel, kecemasan, dan ketakutan hingga menimbulkan stres.

Keterbatasan pemahaman terkait materi yang didapat oleh mahasiswa juga sangat berpengaruh sehingga menyebabkan stres karena tuntutan pada kemampuan mahasiswa untuk mengerjakan tugas pembelajaran. Keterbatasan ruang membuat mereka tidak bisa leluasa bertanya baik kepada dosen pengajar maupun kepada teman. Apalagi sistem pembelajaran daring yang berbeda sehingga materi yang didapat mahasiswa kurang dapat dipahami. Sebenarnya di era sekarang mahasiswa dituntut untuk dapat belajar dengan mandiri. Namun pada kenyataannya tidak semua mahasiswa mampu belajar secara mandiri (Amini et al., 2020).

Manusia merupakan makhluk sosial yang tidak dapat hidup seorang diri dan perlu berinteraksi dengan manusia lainnya (Putri et al., 2020). Di tengah kondisi pandemi seperti ini mahasiswa berpotensi tidak bisa memenuhi kebutuhan psikologisnya yaitu kebutuhan akan keterhubungan (Hasan, 2020) dalam Abbas (2020). Metode belajar tanpa tatap muka dan tanpa interaksi langsung membuat mahasiswa menjadi stres karena tidak dapat bertemu dengan orang- orang yang disayangi termasuk teman perkuliahan. Mereka merasa terisolasi, lelah melihat layar dan tidak ada komunikasi dengan teman-teman.

Internet memberikan kemudahan untuk mencari sumber informasi yang cepat sesuai dengan kebutuhan karena itu umum digunakan oleh masyarakat, tak terkecuali kalangan mahasiswa (Fuadiah et al., 2016). Pada pembelajaran jarak jauh seperti ini kelancaran jaringan internet sangat mempengaruhi kinerja mahasiswa dalam mengikuti pembelajaran. Sulitnya akses internet membuat tugas kuliah menumpuk sehingga menimbulkan stres berlebih pada mahasiswa.

Menurut Susanto \& Azwar (2020) kejenuhan belajar yang dialami para mahasiswa terjadi akibat dari adanya tuntutan bagi mereka untuk selalu mematuhi aturan tugas-tugas yang telah diberikan, mengerjakan kegiatan perkuliahan yang selalu sama di setiap harinya seperti hanya menatap layar laptop kemudian mengerjakan tugas. Hal ini membuat mahasiswa menjadi sensitif. Perilaku yang ditunjukkan seseorang yang mengalami kejenuhan yaitu cepat marah, mudah stres, mudah terluka, dan mudah frustasi (Hidayat, 2016) dalam Pawicara, \& Conilie (2020). 
Sulitnya mengkoordinir pekerjaan kelompok juga menjadi permasalahan yang menyebabkan stres pada beberapa mahasiswa. Ada pun faktor yang menyebabkan stres yaitu adanya perselisihan kesepakatan dengan temannya sendiri, beban kerja yang berlebihan karena tidak membagi tindakan antara teman satu dengan teman yang lainnya (Livana et al., 2020). Belum lagi karena kendala yang dialami anggota kelompok berbeda-beda. Hal ini membuat beberapa anggota kelompok harus mengerjakan bagian dari anggota yang terkendala dan menjadikan pekerjaan mereka kian bertambah.

Tidak ada ketetapan jadwal yang jelas juga membuat mahasiswa menjadi cemas dan akhirnya menjadi stres. Di perguruan tinggi, program penjadwalan merupakan salah satu hal penting dalam proses belajar mengajar, karena semua kegiatan dosen dan mahasiswa bergantung pada jadwal yang ada, sehingga harus disusun dengan benar, sehingga nantinya tidak mengganggu aktivitas belajar mengajar (Ariani et al., 2011). Tapi pada pembelajaran jarak jauh, seringkali jadwal perkuliahan mengalami perubahan dan seringkali dikabarkan mendadak. Hal ini membuat mahasiswa menjadi cemas saat ingin melakukan kegiatan lainnya. Mereka harus selalu stand by di depan layar handphone maupun laptop untuk menunggu kabar karena takut dan khawatir akan tertinggal perkuliahan.

Faktor selanjutnya adalah tidak bisa melakukan hobi seperti biasanya. Hobi adalah kegiatan rekreasi yang dilakukan pada waktu luang untuk menenangkan pikiran seseorang (Verdyanto, 2014). Padatnya perkuliahan online dan banyaknya tugas yang harus dikerjakan membuat mahasiswa harus merelakan waktunya untuk terus menatap layar laptop tanpa bisa melakukan hobi mereka. Padahal melakukan hobi merupakan sarana coping stres setelah mengerjakan sesuatu yang membuat diri merasa lelah.

Pekerjaan rumah yang menumpuk juga menjadi salah satu faktor. Beberapa mahasiswa bahkan merasa tidak memiliki waktu luang untuk mengerjakan pekerjaan rumah. Akibatnya pekerjaan rumah juga ikut menumpuk, seperti halnya mencuci pakaian, membersihkan kamar, dan lain sebagainya. Apalagi ditambah dengan orangtua yang kurang paham terhadap kesibukan anaknya hingga timbul perasaan marah dan menganggap anak tidak membantu mereka sama sekali. Hal ini membuat mahasiswa kian stres setiap harinya.

Pandemi covid-19 juga mengakibatkan perubahan dalam hubungan keluarga. Mahasiswa yang terlalu sibuk 
dengan tugas akademik membuat hubungannya dengan keluarga menjadi renggang. Mereka mulai jarang melakukan komunikasi keluarga dan hanya berdiam diri di dalam kamar sambil mengerjakan tugas. Fungsi komunikasi sebagai komunikasi sosial setidaknya mengisyaratkan bahwa komunikasi itu penting untuk membangun konsep diri, aktualisasi diri, dan untuk kelangsungan hidup, untuk memperoleh kebahagiaan, untuk menghindarkan diri dari tekanan dan ketegangan, misalnya melalui komunikasi yang menghibur dan memupuk hubungan baik dengan orang lain (Watuliu, 2015).

Faktor pemicu timbulnya gejala stres lainnya adalah pembelajaran jarak jauh menghabiskan kuota internet yang sangat sangat banyak. Menurut Hasan (2020) dalam Abbas (2020) proses belajar dan mengajar model online membebani mahasiswa dari segi biaya dan mental. Beberapa mahasiwa mengalami hal ini dikarenakan keterbatasan dana untuk membeli kuota internet. Kondisi tersebut diperparah dengan kondisi keuangan keluarga yang dalam beberapa kasus juga bermasalah akibat dari pandemi ini (Muslim, 2020).

Hal ini juga menjadi tantangan tersendiri bagi mahasiswa baru yang masih dalam tahap beradaptasi dengan lingkungan perkulihan. Pada awal menempuh pendidikan di perguruan tinggi, mahasiswa dihadapkan pada berbagai macam tantangan dan perubahan dalam hidup (Maulina, 2018). Kini tidak hanya perbedaan proses pembelajaran antara sekolah menengah dengan perguruan tinggi yang menuntut mahasiswa baru untuk beradaptasi, tetapi juga tantangan dari perkuliahan jarak jauh yang membuat mereka harus bekerja lebih keras dalam melakukan penyesuaian. Menurut Sukoco (2014) Mahasiswa baru yang gagal dalam beradaptasi terhadap tuntutan di perkuliahan dapat mengalami stres.

Terakhir, mahasiswa yang berada di quarter life crisis juga sangat rentan mengalami stres di masa pandemi. Quarter life crisis adalah perasaan yang muncul saat individu mencapai usia pertengahan 20-an tahun, dimana ada perasaan takut terhadap kelanjutan hidup di masa depan, termasuk di dalamnya urusan karier, relasi dan kehidupan sosial (Afnan et al., 2020). Hal ini biasanya dialami oleh para mahasiswa yang sedang berada di akhir perkuliahan atau di tahapan pengerjaan skripsi. Pandemi yang mengharuskan mahasiswa melakukan pembelajaran jarak jauh tak terkecuali mahasiswa tingkat akhir membuat mereka mengalami stres akademik. Tugas-tugas lapangan tidak dapat dilakukan secara 
langsung, membuat mahasiswa harus mengganti topik pembahasan, bahkan tidak sedikit yang menunda untuk menyelesaikan tugas akhir (Muslim, 2020).

\section{KESIMPULAN}

Penyebab munculnya gejala stres pada mahasiswa akibat dampak pembelajaran jarak jauh di masa pandemic covid-19 yaitu tugas perkuliahan, lingkungan belajar, kebisingan, keterbatasan pemahaman terkait materi yang didapat, tidak dapat bertemu dengan orang-orang yang disayangi termasuk teman perkuliahan, jaringan internet yang terkendala, sulitnya pengerjaan tugas kelompok, tidak bisa melakukan hobi seperti biasa, pekerjaan rumah yang menumpuk, kuota internet yang boros, sulit mengkoordinir tugas kelompok, tidak ada ketetapan jadwal perkuliahan, tidak bisa melakukan hobi seperti biasa, pekerjaan rumah yang menumpuk, perubahan hubungan keluarga, tidak bisa beradaptasi, serta kejenuhan yang dialami saat pembelajaran jarak jauh.

\section{SARAN}

Stres sendiri memiliki efek yang tidak bisa dianggap remeh. Akumulasi stres menyebabkan frustrasi, depresi, dan kecemasan, dan dapat menyebabkan perhatian pada gangguan hiperaktif, penyalahgunaan zat, antisosial perilaku, dan bahkan kekerasan (Putri, 2014). Agar hal tersebut tidak sampai terjadi, mahasiswa disarankan untuk memanajemen stres. Menurut Abbas (2020) memanage psikologis itu penting dan setiap manusia mempunyai pikiran, perasaan, dan dirinya sendiri yang bisa memanage-nya. WHO dalam Muslim (2020) merumuskan strategi untuk menghadapi stres selama pandemi Covid-19 yaitu yang berbincang dan berbagi cerita dengan orang-orang yang dapat dipercayai, menjaga gaya hidup sehat dengan asupan gizi yang cukup, pola tidur yang baik, olahraga dan berinteraksi dengan orang-orang yang disayang bisa dilakukan selama berdiam di rumah, mencari fakta-fakta dan info terbaru yang dapat membantu dalam menentukan tahap pencegahan yang tepat dan menghindari berita-berita yang tidak valid dan kredibel, mengurangi kecemasan dengan membatasi media yang menyebarkan informasi yang membuat semakin cemas dan takut, dan mengoptimalkan kemampuan yang dimiliki untuk mengatur emosi selama masa pandemi ini.

\section{DAFTAR PUSTAKA}

Abbas, E. W., \& Erlyani, N. (2020). Menulis di Kala Badai Covid-19. 
Afnan, A., Fauzia, R., \& Tanau, M. U. (2020). HUBUNGAN EFIKASI DIRI DENGAN STRESS PADA MAHASISWA YANG BERADA DALAM FASE QUARTER LIFE CRISIS. Jurnal Kognisia: Jurnal Mahasiswa Psikologi Online, 3(1), 23-29.

Amini, M., Mayangsari, M. D., \& Zwagery, R. V. (2020). Hubungan antara Kemandirian Belajar dengan Komitmen Tugas pada Mahasiswa Program Studi Psikologi. Jurnal Kognisia: Jurnal Mahasiswa Psikologi Online, 2(2), 149-152.

Anward, H. H., \& Erlyani, N. (2016). Peranan conscientiousness terhadap perilaku cyberloafing pada mahasiswa. Jurnal Ecopsy, 3(1).

Argaheni, N. B. Sistematik Review: Dampak Perkuliahan Daring Saat Pandemi COVID-19 Terhadap Mahasiswa Indonesia. PLACENTUM: Jurnal Ilmiah Kesehatan dan Aplikasinya, 8(2), 99-108.

Ariani, D., Fariza, A., \& Prasetyaningrum, I. (2011). Optimasi penjadwalan mata kuliah di jurusan teknik informatika pens dengan menggunakan algoritma particle swarm optimization (pso). EEPIS Final Project.

BintangVerdyanto, Y., Riskiyanto, R., \& Indrosaptono, D. (2014). Semarang Airsoft Headquarter (Doctoral dissertation, Fakultas Teknik Universitas Diponegoro).

Firman, F. (2020). Dampak Covid-19 terhadap Pembelajaran di Perguruan Tinggi. BIOMA: Jurnal Biologi dan Pembelajarannya, 2(1), 14-20.

Handarini, O. I., \& Wulandari, S. S. (2020). Pembelajaran Daring Sebagai Upaya Study From Home (SFH) Selama Pandemi Covid 19. Jurnal Pendidikan Administrasi Perkantoran (JPAP), 8(3), 496-503.
Hasanah, A., Lestari, A. S., Rahman, A. Y., \& Daniel, Y. I. (2020). Analisis aktivitas belajar daring mahasiswa pada pandemi Covid-19.

Hasanah, F. N., \& Setiawan, T. (2020). Pembelajaran Daring di Masa Pandemi Covid-19 pada Perguruan Tinggi Keagamaan Islam Negeri (Studi di IAIN Pekalongan). Indonesian Journal of Educational Science (IJES), 3(1), 12-23.

Hasanah, F. N., \& Setiawan, T. (2020). Pembelajaran Daring di Masa Pandemi Covid-19 pada Perguruan Tinggi Keagamaan Islam Negeri (Studi di IAIN Pekalongan). Indonesian Journal of Educational Science (IJES), 3(1), 12-23.

Irawati, D. Y., \& Jonatan, J. (2020). Evaluasi Kualitas Pembelajaran Online Selama Pandemi Covid-19: Studi Kasus di Fakultas Teknik, Universitas Katolik Darma Cendika. Jurnal Rekayasa Sistem Industri, 9(2), 135-144.

Khofifah, N., \& Minsih, S. A. (2016). Pengaruh Manajemen Kelas Dan Keaktifan Belajar Terhadap Prestasi Belajar Kelas Tinggi SD Negeri Tunjungsari Tahun Ajaran 2015/2016 (Doctoral dissertation, Universitas Muhammadiyah Surakarta).

Le, N. K., Le, A. V., Brooks, J. P., Khetpal, S., Liauw, D., Izurieta, R., \& Reina Ortiz, M. (2020). Impact of government-imposed social distancing measures on COVID-19 morbidity and mortality around the world. Bull World Health Organ, 10.

Livana, P. H., Mubin, M. F., \& Basthomi, Y. (2020). " Learning Task" Attributable to Students' Stres During the Pandemic Covid- 
19. Jurnal Ilmu Keperawatan Jiwa, 3(2), 203-208.

Mahmudah, S. R. (2020). Pengaruh Pembelajaran Daring terhadap Psikologis Siswa Terdampak Social Distancing Akibat Covid 19. AlMau'izhoh, 2(2).

Maihayana, M., Anward, H. H., \& Mayangsari, M. D. (2020). PERBEDAAN KESESAKAN PADA MAHASISWA FAKULTAS KEDOKTERAN (PSIKOLOGI, ILMU KEPERAWATAN, KESEHATAN MASYARAKAT) YANG TINGGAL DI RUMAH SENDIRI, TINGGAL DI KOS DAN TINGGAL DI ASRAMA DI BANJARBARU. Kognisia prodi Psikologi FK ULM, 2(2), 25-36.

Maulina, B., \& Sari, D. R. (2018). Derajat Stres Mahasiswa Baru Fakultas Kedokteran Ditinjau Dari Tingkat Penyesuaian Diri Terhadap Tuntutan Akademik. Jurnal Psikologi Pendidikan dan Konseling: Jurnal Kajian Psikologi Pendidikan dan Bimbingan Konseling, 4(1), 1-5.

Mayangsari, M. D., \& Astuti, J. P. (2018). FAKTOR YANG MEMPENGARUHI KINERJA KOGNITIF PADA MAHASISWA DI TINJAU DARI PENGATURAN RUANG KELAS. Jurnal Ecopsy, 5(3).

Muslim, M. (2020). MANAJEMEN STRES PADA MASA PANDEMI COVID19. ESENSI: Jurnal Manajemen Bisnis, 23(2), 192-201.

Pajarianto, H., Kadir, A., Galugu, N., Sari, P., $\&$ Februanti, S. (2020). Study from Home in the Middle of the COVID19 Pandemic: Analysis of Religiosity, Teacher, and Parents Support Against Academic Stres. Journal of Talent Development and Excellence, 12(2s), 1791-1807.
Pawicara, R., \& Conilie, M. (2020). Analisis Pembelajaran Daring terhadap Kejenuhan Belajar Mahasiswa Tadris Biologi IAIN Jember di Tengah Pandemi Covid19. ALVEOLI: Jurnal Pendidikan Biologi, 1(1), 29-38.

Pawicara, R., \& Conilie, M. (2020). Analisis Pembelajaran Daring terhadap Kejenuhan Belajar Mahasiswa Tadris Biologi IAIN Jember di Tengah Pandemi Covid19. ALVEOLI: Jurnal Pendidikan Biologi, 1(1), 29-38.

Purwaningsih, H. (2020, August). Analisis Masalah Psikologis pada Ibu Hamil Selama Masa Pandemi Covid-19: Literature Review. In CALL FOR PAPER SEMINAR NASIONAL KEBIDANAN (Vol. 1, No. 1, pp. 9$15)$.

Putri, L. A., Anward, H. H., \& Zwagery, R. V. (2020). PERBEDAAN KUALITAS PERSAHABATAN DITINJAU DARI GAYA KELEKATAN PADA MAHASISWA PSIKOLOGI FAKULTAS KEDOKTERAN ULM. Kognisia prodi Psikologi FK ULM, 1(1), 23-28.

Putri, W. D. A. W. (2014). Prevalensi stres psikososial dan faktor-faktor yang mempengaruhi pada siswa-siswi kelas XII studi Pendidikan IPA dan IPS SMAN 6 Denpasar. Fakultas Kedokteran Udayana.

Rachmah, D. N., Mayangsari, M. D., \& Akbar, S. N. (2015). Motivasi belajar sebagai mediator hubungan kecerdasan adversitas dan prokrastinasi akademik pada mahasiswa yang aktif berorganisasi. Jurnal Cakrawala Pendidikan, 34(2).

Rahmawati, R., \& Putri, E. M. I. (2020, June). Learning From Home dalam Perspektif Persepsi Mahasiswa Era 
Pandemi Covid-19. In Prosiding Seminar Nasional Hardiknas (Vol.

1, pp. 17-24).

Sadikin, A., \& Hamidah, A. (2020). Pembelajaran Daring di Tengah Wabah Covid-19:(Online Learning in the Middle of the Covid-19 Pandemic). Biodik, 6(2), 214-224.

Sandra, R., \& Ifdil, I. (2015). Konsep Stres Kerja Guru Bimbingan dan Konseling. Jurnal EDUCATIO: Jurnal Pendidikan Indonesia, 1(1), 80-85.

Sukoco, A. S. P. (2014). Hubungan sense of humor dengan stres pada mahasiswa baru Fakultas Psikologi. CALYPTRA, 3(1), 1-10.

Susanto, S., \& Azwar, A. G. (2020). ANALISIS TINGKAT KELELAHAN PEMBELAJARAN DARING DALAM MASA COVID19 DARI ASPEK BEBAN KERJA MENTAL (Studi Kasus Pada Mahasiswa Universitas Sangga Buana). TECHNO-SOCIO EKONOMIKA, 13(2), 102-112.

Wahyuni, L. T. (2018). Hubungan Stres dengan Kualitas Tidur Mahasiswa Profesi Keperawatan STIKes Ranah Minang Padang Tahun 2016. Menara Ilmu, 12(3).

WARMANSYAH ABBAS, E. R. S. I. S. (2020). Menulis di Era Covid-19: Memanage Trauma Psikologis Menghindari Psikosomatis. Menulis di Era Covid-19: Memanage Trauma Psikologis Menghindari Psikosomatis.

Watuliu, J. (2015). Peranan Komunikasi Keluarga Dalam Meningkatkan Minat Belajar Siswa Smu Di Desa Warukapas Kecamatan Dimembe Kabupaten Minahasa Utara. ACTA DIURNA KOMUNIKASI, 4(4).

Zwagery, R. V., \& Dewi, R. S. PENGARUH KEBISINGAN TERHADAP DAYA INGAT PADA REMAJA. 